\title{
楔デバイスを用いたセルフセンタリング鉄骨架構の耐震性能に関する研究 STUDY ON SEISMIC PERFORMANCE OF SELF-CENTERING STEEL FRAME WITH WEDGE DEVICE
}

\author{
景山朋定*, 高松隆夫**, 玉井宏章***, \\ 山西央朗****, 國井翔平*****, 岩瀬 貴 信* \\ Tomosada KAGEYAMA, Takao TAKAMATSU, Hiroyuki TAMAI, \\ Teruaki YAMANISHI, Shohei KUNII and Takanobu IWASE
}

\begin{abstract}
Steel frames retain residual deformation after a huge earthquake, their continued use is impractical. This paper aims to decrease residual deformation by use of connections incorporating a wedge device. A loading test on a specimen with a beam joint connected by conventional bolts and using such a device shows that its restoring force characteristics are of the linear-from-origin type. Seismic response analyses of steel frames with such wedge device connections lead to the following conclusions: they show no residual deformation; and story deformation angles, story shear forces, story shear coefficients, and energy absorption capability are equivalent to those for rigid frames. Furthermore, plastic deformation behavior of the wedge device connection is superior to that of rigid frames.
\end{abstract}

Keywords: Self-centering performance, Residual deformation, Wedge device connection, Loading test, Numerical analysis, Steel frame セルフセンタリング性能，残留変形，楔デバイス付接合部，載荷実験，数值解析，鉄骨架構

\section{1. 序論}

現在の耐震設計では, 保有水平耐力設計法 ${ }^{1)}$ が広く用いられてい る. 保有水平耐力設計法は, 大地震時において, 架構を構成する構 造部材に塑性ヒンジを生成させることで，構造部材の塑性変形によ り地震入力エネルギーを消費させる勒性型の設計法である. 塑性ヒ ンジを梁端部や柱脚部に生成させ，全体層崩壊機構となるよう設計 すれば，エネルギー吸収効率が良く，部分層崩壊等にみられる損傷・ 変形集中も回避できるため倒壊を防ぐことが可能となる（以降，こ のように設計された架構を梁降伏型架構と記す)。特に, 鋼構造建築 物であれば構造部材の復元力特性が完全弾塑性型となるため, 地震 時応答の低減，安定が期待できる．しかしながら，鋼構造架構に塑 性ヒンジを生成させる場合には，いくつかの問題点を抱えている.

その一つは，大地震を受けた構造物の地震後継続使用の問題であ る. 公的機関や防災拠点のように，災害時にその機能が発揮される べき建物や，集合住宅のように，市民の生活拠点である建物は，地 震直後においても，継続使用できることが望まれる．しかしながら， 地震時に全体層崩壊機構が形成された場合, 残留変形が生じるため, その変形が大きければ建物としての機能が維持できなくなる可能性 がある. 更に, 補修においても, 多大な資金と期間が必要であり, 場合によっては，補修が不可能で取り壊さざるを得なくなる．また， 残留変形によってドアや空の開閉が不可能となれば，避難・救助が
困難になる ${ }^{2)}$.

他には，塑性ヒンジの性能確保の問題である．梁降伏型架構にお いては，梁端部に塑性ヒンジが生成されるため，梁端部溶接接合部 の耐力・勒性を十分に確保する必要がある。しかしながら，兵庫県 南部地震の被害例として, 不十分な品質管理等に起因した, 柱梁接 合部の溶接部が破断した事例が多く報告されている ${ }^{2)}$. また，保有水 平耐力設計法では, 塑性変形性能は幅厚比により判定される. FA ラ ンクの幅厚比を有する部材においても，多数の繰返し載荷回数や過 大な地震荷重を受けた場合には，局部座屈を生じる恐れがある ${ }^{3,4)}$. 局部座屈による不安定挙動を原因として, 塑性ヒンジは耐力・勒性 を維持できず，構造物の耐震性能は著しく劣化する.

上述の問題点を解決するため, 国内外で様々な対策・研究が成さ れている. 残留変形の低減については, 構造物にセルフセンタリン グ性能と呼ばれる原点指向型復元力特性を付与寸ることが効果的で あることが明らかとなっており ${ }^{5-8)}$ ，文献 9) ではセルフセンタリング に関する様々な研究が報告されている. 文献 5)の工法は, 柱と梁の 接合に用いるアングルをエネルギー吸収要素とするため大きなエネ ルギーを吸収できず，PC 鋼棒をフレーム全体に使用するため大掛か りなものとなる．また，文献 6) ではセルフセンタリング接合部を適 用した架構の数值解析を行い, 残留変形は低減できても応答変形が 大きくなるという問題点を示している.

\footnotetext{
$*$ 広島工業大学大学院工学系研究科 大学院生

** 広島工業大学工学部建築工学科 教授. Ph.D

*** 長崎大学工学部工学科 教授・博士 (工学)

**** 広島大学大学院建築学専攻 助教・博士 (工学)

***** 大旗連合建築設計侏) 修士(工学)
}

Grad. Stud., Grad. School of Sci. \& Tech.. Hiroshima Institute of Technology Prof., Dept. of Architectural Eng., Hiroshima Institute of Technology, Ph.D. Prof., Dept. of Eng., Nagasaki University, Dr.Eng.

Assist. Prof., Grad. School of Eng., Hiroshima University, Dr.Eng.

Oh-hata Architects \& Partners, M.Eng. 
著者等は楔デバイスを用いた露出柱脚であるノンスリップ型露出 柱脚 ${ }^{10-13)}$ の研究を行い, 柱脚のみにセルフセンタリング性能を与え ても構造物全体の残留変形を低減できないという結果を得ている ${ }^{13)}$. 更に，構造物全体の残留変形低減を目指して提案した柱梁接合部を ボルト接合とする工法である楔デバイス付柱梁接合部 ${ }^{14,15)}$ では, 残 留変形は低減できたものの, 他の研究と同様に, 最大層間変形角が

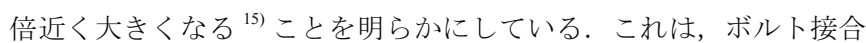
部を降伏させるために接合部耐力を低下させる必要があり, これに より架構の耐力や剛性が低くなるためである.

そこで，本論文の目的は，これらの問題を解決する構造システム の提案を行い, その耐震性能を明らかにすることである. 方法として, 先ず, 構造システムの提案を行い, 次に, 載荷実験でその性能を確 かめる．最後に数值解析により耐震性能を明らかにする.

\section{2. 構造システム}

\section{1 楔デバイス付接合部概要}

楔デバイス付接合部は，エンドプレート形式のボルト接合部に楔 デバイスを設置したものである．特に露出柱脚をノンスリップ型露 出柱脚と呼び，梁継手を楔デバイス付梁継手と呼ぶ，ノンスリップ 型露出柱脚の作動概念と復元力特性を図 1 に示寸. 柱脚に曲げモー メントが作用すると，アンカーボルトが伸ばされ，降伏すれば塑性 伸びを生じる (図 1 中, $\mathrm{O} \rightarrow \mathrm{A} \rightarrow \mathrm{B}$ )。除荷により柱脚回転角 $\theta$ が 0 に戻る場合，ナットとベースプレート間に間隙が発生するが，この 間隙にばねにより楔を貫入させることで間隙が消滅する（図 1 中, $\mathrm{C} \rightarrow \mathrm{O})$. このため, 再載荷時にも柱脚は緩むことなく即座に曲げモー メントに抵抗し，再び図 1 中， $\mathrm{O} \rightarrow \mathrm{A}$ のような経路をたどる．尚，曲 げモーメントが大きく, ベースプレート中央にあるボルトも降伏す る場合は図 1 中 $\mathrm{O} \rightarrow \mathrm{A} \rightarrow \mathrm{D} \rightarrow \mathrm{E} \rightarrow \mathrm{F} \rightarrow \mathrm{G} \rightarrow \mathrm{O}$ の経路をたどる。このとき に原点指向型復元力特性は得られないが，常に原点から立上りを生 じるセルフセンタリング性能に類似した原点立上り型復元力特性が 得られる.

\section{2 楔デバイス付梁継手}

図 2 に示寸楔デバイス付梁継手は, 梁継手を長締めボルトで接合 する工法である，抵抗機構はノンスリップ型露出柱脚と同様で，ボ ルトがエネルギー吸収要素となる。楔デバイス付梁継手は図 2(a) の
ように構成される，ブラケットを設けるため，柱の両側並びに直交 方向へも梁を設けられる，更に，ブラケット長さにより継手位置を 調整でき, 図 2(b) のような耐力関係（柱フェイス位置に作用寸る曲 げモーメントが梁の全塑性モーメント ${ }_{B} M_{P}$ となるようなブラケット 長さ ${ }_{B R} L$ と接合部最大曲げモーメント $\left.{ }_{j} M_{U}\right)$ で設計すればボルト降伏 型の接合部でありながら, 架構の保有水平耐力を低下させない設計 が可能となる. また，ボルトプレート位置によってボルト有効長さ を変えることができ，接合部曲げ耐力を変更することなく回転剛性 を調整できる，接合ボルトには $10 \%$ の伸び性能が保証された転造ね じアンカーボルト ${ }^{16)}$ を用いる. ボルトを長くすれば剛性が低下寸る が, 変形性能が大きくなる.

楔デバイス付梁継手のブラケット長さ ${ }_{B R} L$ は, 以下の式を用いて算 定する.

${ }_{B R} L=L-\alpha_{j} \cdot L$

ここに, $L$ : 柱フェイス間距離の半分, $\alpha_{j}$ : 接合部負担耐力係数で ある。

その他の設計条件を以下に示寸.

ブラケットの断面性能は，梁の全塑性モーメントに対して弾性状 態を保つよう設計する。ただし，エンドプレート間の接触反力の 伝播を考慮し，梁と同一の成とする.

ブロック部の断面は, 圧縮合力点位置に作用する圧縮力に対し, 座屈しない断面とする.

ボルトプレートは，ボルトの引張抵抗に対して弾性状態を保つ板 厚とする.

せん断力に対する抵抗は，長期荷重に対してはボルトに導入した 初期軸力による摩擦力により, 短期荷重に対しては, 曲げモーメ ントによって生じる接触反力により発生する摩擦力が抵抗するも のとする.

ボルトの有効長さは, 繰返しの地震力に対して十分な塑性伸びが 期待できる長さ（転造ねじアンカーボルトの保証伸び性能である $10 \%$ 以下）とする.

\section{3. 楔デバイス付梁継手の載荷実験}

本節では，楔デバイス付梁継手の復元力特性を確認することを目 的とした載荷実験を行う.

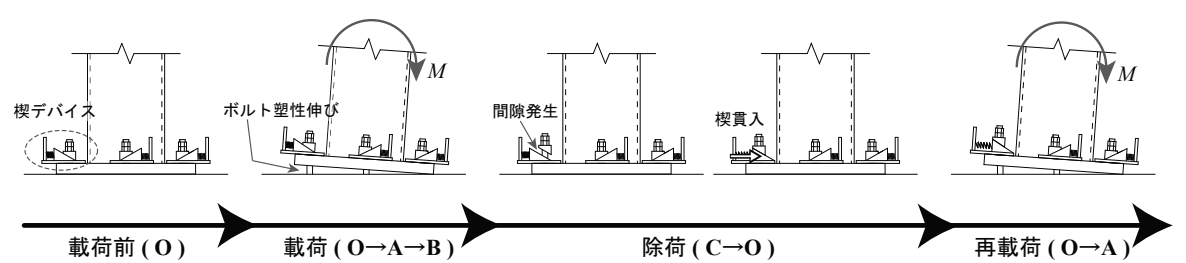

(a) 作動概念

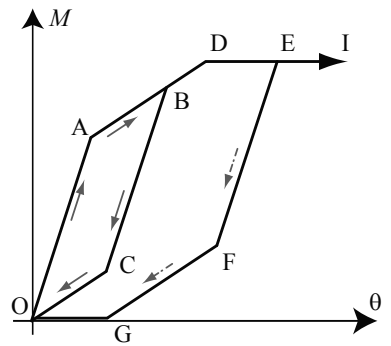

(b) 原点立上り型復元力特性

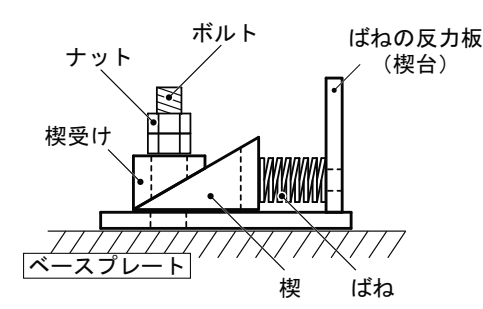

(c) 楔デバイスの構成
図 1 ノンスリップ型露出柱脚

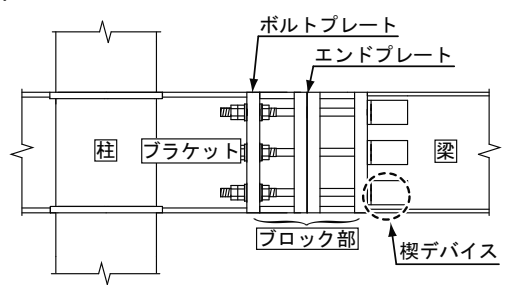

(a) ディテール

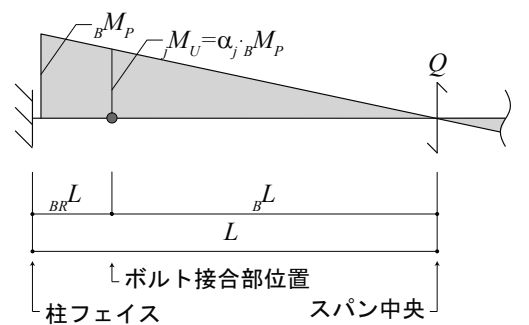

(b) 力学モデル

図 2 楔デバイス付梁継手 


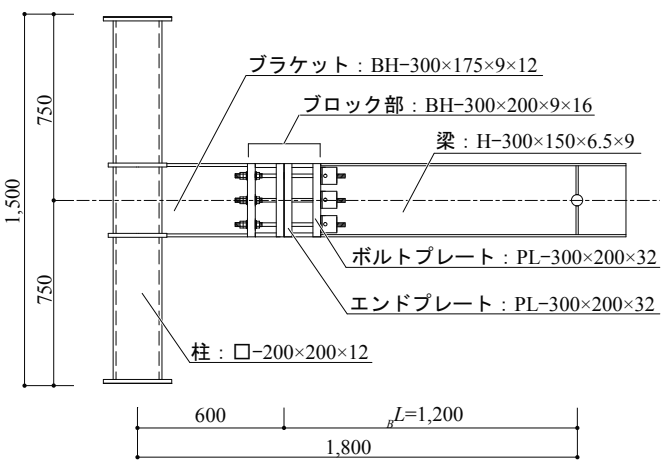

(a) 立面図

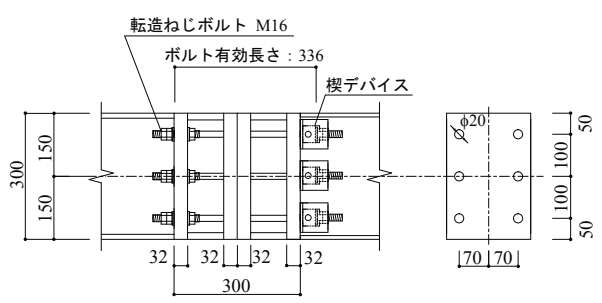

(b) 接合部詳細図

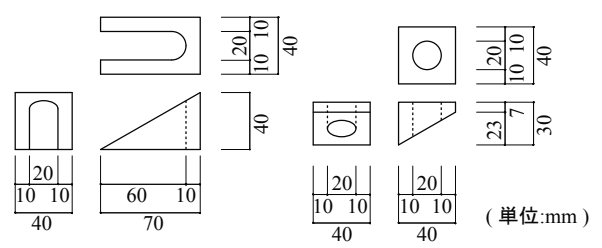

(c) 楔デバイス寸法

図 3 試験体

\section{1 試験体}

試験体を図 3 に，試験体の素材特性を表 1 に示す，試験体は，柱 とそれに取付く梁を想定し，水平荷重に対する曲げモーメント反 曲点位置までを取出した部分架構を用いる，部材として，柱には $\square$ $-200 \times 200 \times 12$ を，梁には H-300×150×6.5×9 を，ブラケットには BH$300 \times 175 \times 9 \times 12$ を，ブロック部には BH-300×200×9×16 を用いる．接合 ボルトには転造ねじアンカーボルトM16を使用している，ボルトは 3 列で 1 列に 2 本ずつ, 計 6 本を配置し, 楔デバイスを介してダブ ルナットにより梁とブラケットを緊結する. 尚, 継手ディテールは, 楔デバイスの配置上図 3(b) に示すような構成を基本ディテールとす る。また，エンドプレート・ボルトプレート厚はボルト径の 2 倍で ある $32 \mathrm{~mm}$ として面外変形に対して安全側の設計をしている. エン ドプレート厚は, せん断力および継手部の回転中心となることによ る圧縮力を伝達できればいいため, 薄くすることが可能である. また, エンドプレートの接触面にはせん断力伝達を目的とした発錆処理を 行っている. 楔デバイスはSS400の鋼塊から図3(c)のように切削成 形後, 発錆処理（塩分濃度 $10 \%$ 程度の食塩水により, 1 週間ほど湿 潤状態を保つ）を施して, 静止摩擦係数が 0.58 以上となるようにし ている.

本試験体のブラケット長さ ${ }_{B R} L$ は, 接合部負担耐力係数 $\alpha_{j}$ を 0.7 と して, 式(1) で設計している. しかしながら, 本載荷実験では, 本工 法を用いることによって, 原点立上り型復元力特性が得られること の確認を目的としているため, ボルト接合部の耐力を低目（接合部

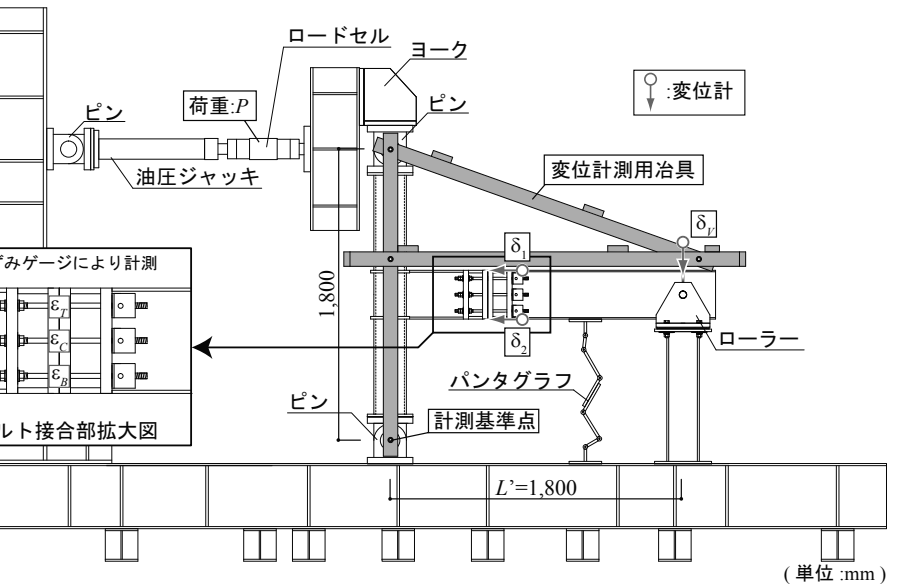

図 4 載荷装置と計測位置 表 1 試験体の素材特性

\begin{tabular}{|c|c|c|c|c|c|}
\hline 部材 & 材質 & $\begin{array}{c}\sigma_{Y} \\
\left(\mathrm{~N} / \mathrm{mm}^{2}\right)\end{array}$ & $\begin{array}{c}\sigma_{U} \\
\left(\mathrm{~N} / \mathrm{mm}^{2}\right)\end{array}$ & $\begin{array}{c}\sigma_{Y} / \sigma_{U} \\
(\%)\end{array}$ & $\begin{array}{c}\varepsilon_{f} \\
(\%)\end{array}$ \\
\hline 柱 & $\begin{array}{l}\text { STKR400 } \\
\end{array}$ & 460 & 515 & 89 & 19 \\
\hline 梁フランジ & SS400 & 311 & 440 & 74 & 31 \\
\hline 梁ウェブ & SS400 & 362 & 460 & 80 & 23 \\
\hline ブラケットフランジ & SS400 & 342 & 469 & 73 & 27 \\
\hline ブラケットウェブ & SS400 & 361 & 440 & 84 & 26 \\
\hline ブロック部フランジ & SS400 & 288 & 432 & 68 & 31 \\
\hline ブロック部ウェブ & SS400 & 374 & 447 & 85 & 23 \\
\hline 転造ねじボルト & ABR400 & 287 & 444 & 66 & 32 \\
\hline
\end{tabular}

負担耐力係数 0.3 程度）にしている. 実験はボルトの初期導入張力と してボルト降伏軸力の $30 \%$ を導入し, 張力管理はひずみゲージから 得られたひずみ度をボルト軸力に換算して行っている.

\section{2 載荷装置と載荷方法}

載荷装置と計測位置を図 4 に示す。載荷は, 試験体の柱上端に取 付けたピンにヨークを介して設置した油圧ジャッキによって行う. 油圧ジャッキは, 載荷装置の反力柱に取付け, 試験体柱上部のピン 中心とジャッキ軸心が一致するように設置している. 試験体の支持 状態としては, 柱下端部をピン支持, 梁先端をローラー支持として いる. また, 梁の横振れ止めとして, 梁中央部にパンタグラフを設 置している. 尚, 梁端部はローラー支持状態を作り出すため, スラ イドベアリングを用い, 引張載荷時に作用する浮上り反力に対して は, ダブルナットで接合した普通ボルトにより抵抗させている.

載荷は, 層間変形角 $r$ を制御値とした正負交番漸増繰返し載荷とし, ボルト弾性域載荷として層間変形角 $1 / 1000,1 / 500 \mathrm{rad}$ につて, 各 2 サイクルずつ, ボルト弾塑性域載荷として $1 / 200,1 / 100,1 / 50 \mathrm{rad}$ ついて, 各 2 サイクルずつ行う.

\section{3 計測方法と整理方法}

変位としては, 変位計測用治具の回転に伴い生じるローラー支点 位置でのその治具の鉛直変位 $\delta_{V}$ を計測し,$\delta_{V}$ から層間変形角 $r$ を算 出する. 継手上下の $\delta_{1} \cdot \delta_{2}$ により, エンドプレート回転角 $\theta$ を算出 する. 荷重として, 油圧ジャッキ先端のロードセルにより, 荷重 $P$ を計測する. また, ひずタとしては, 接合部の各ボルト（1 本当たり 2 箇所）に貼付けたひずみゲージにより計測する.

層間変形角 $r$, エンドプレート回転角 $\theta$, 継手部曲げモーメント ${ }_{j} M$ を，以下の式によって算定する. 
$r=\frac{\delta_{V}}{L^{\prime}}$

${ }_{j} M=P \cdot{ }_{B} L$

$\theta=\frac{\delta_{1}-\delta_{2}}{D}$

ここに, $L^{\prime}:$ 柱心からローラー支点までの距離 $(1,800 \mathrm{~mm}),{ }_{B} L:$ ロー ラー支点から梁継手までの距離 $(1,200 \mathrm{~mm}), D: \delta_{1}$ と $\delta_{2}$ の変位計間の 距離である。

\section{4 復元力特性モデル}

抵抗機構を図 5 に, 復元力特性モデルを図 6 に示す。抵抗機構と して，最外列および中央列ボルトのみが抵抗するものとし，曲げ耐 力を算定する. 継手部の回転中心となる圧縮合力点位置はエンドプ レート端部と仮定寸る.

$i$ 列のボルト降伏曲げモーメント ${ }_{j} M_{Y i}, i$ 列のボルトの弾性回転剛性 ${ }_{j} K_{i}$ は次式により求める.

$$
\begin{gathered}
{ }_{j} M_{Y i}=n_{i} \cdot A \cdot \sigma_{Y} \cdot d_{i} \\
K_{j}=\frac{E \cdot n_{i} \cdot A \cdot d_{i}^{2}}{R \cdot l_{b}}
\end{gathered}
$$

ここに, $n_{i}$ : 各列のボルト本数, $A$ : ボルト断面積, $\sigma_{Y}$ : ボルト降 伏応力度, $d_{i}$ : 圧縮合力点位置から各列ボルト軸心までの距離, $l_{b}$ : ボルト有効長さ, $R$ : ボルト以外の弾性変形を考慮した低減係数であ り，R=2 $2^{17)}$ を採用している.

復元力特性モデル算定式を以下に示す.

$$
\begin{aligned}
& M_{j}={ }_{j} M_{Y 1}+\frac{d_{2}}{d_{1}} M_{j} M_{Y 2} \\
& M_{U}={ }_{j} M_{Y 1}+{ }_{j} M_{Y 2} \\
& K_{I}=K_{j}+K_{j} K_{2} \\
& K_{J}=K_{j} K_{2}
\end{aligned}
$$

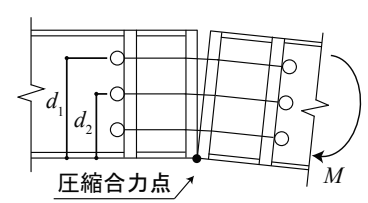

図 5 抵抗機構

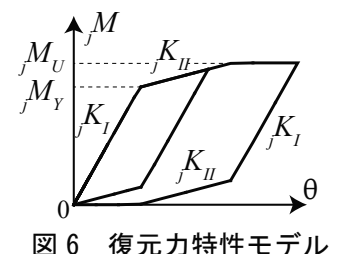

図 6 復元力特性モデル
ここに, ${ }_{j} M_{Y}$ : 接合部降伏曲げモーメント, ${ }_{j} M_{U}$ : 接合部最大曲げモー メント, ${ }_{j} K_{I}$ : 弾性剛性, ${ }_{j} K_{I I}: 2$ 次勾配である. 尚, ボルト列数が複 数の場合, 後述する式 (11), (12) による.

\section{5 実験結果とその考察}

実験結果を図 7 に示す．図7(a)には，解析值および原点近傍の拡 大図（1/200rad-2 サイクル目）を併せて示す，図 7(b) はひずみゲー ジにより計測したボルトのひずみ度である。ボルトが降伏し，降伏 棚に入るとひずみ度が著しく大きくなるため，1/100-1 サイクル目ま での結果を示す。

図 7(a) を見ると原点立上り型復元力特性を示すことがわかる．実 験值と解析值の対応について, 載荷時においては 1/100rad-1 サイク ル以前で初期剛性が若干増加し，その後弾性剛性は解析值と対応寸 る. それ以降のサイクルにおいて, 実験值の弾性剛性が低目となっ ている．また，降伏曲げモーメントは低目となり，最大曲げモーメ ントは高目となる. 先ず，初期剛性が若干増加することについては, 初期導入張力により，理論上それ以上のモーメントが作用しないと
回転が生じないと考えられ，初期剛性が増加する.しかしながら， 製作誤差（溶接等）による影響で接合面に間隙があり，載荷時に間 隙を埋めようとしてわずかに回転が生じ，結果的に初期剛性が若干 増加している. 尚, 初期張力が消失する $1 / 200 \mathrm{rad}-2$ サイクル目の剛 性は良好に対応している. 次に, 弾性剛性・降伏曲げモーメントの 低下については, 中央列ボルトの抵抗の遅れに起因寸る. 図 7(b) 中 $i$ に示すように，1/200 $\mathrm{rad}$ 以降のサイクルにおいて，エンドプレート回 転角 0 付近でわずかに抵抗が遅れており，中央列ボルトの抵抗が小 さくなったために降伏曲げモーメントが低下した。 これは, ボルト の塑性化により初期軸力が抜けた後, 中央列ボルトに緩みが生じた ためである．最後に，最大曲げモーメントの上昇については，ボル トのひずみ硬化による影響や，復元力特性モデルでは考慮していな かった最内列ボルトの抵抗のためである (図 7 中 $j$ 点).

以上のことから，楔デバイス付梁継手は原点立上り型復元力特性 を示し, 評価式によって概ね評価できることがわかる。しかしながら， 本試験体はボルト接合部の耐力を低目に設計しており, 架構の保有 水平耐力を低下させない程度まで耐力を増加させると, エンドプレー トおよびボルトプレートの局所変形が大きくなることが予想され， 復元力特性への影響が懸念される. 今後, 適正なプレート厚さにつ いて実験や FEM 解析を行い検討する必要がある.

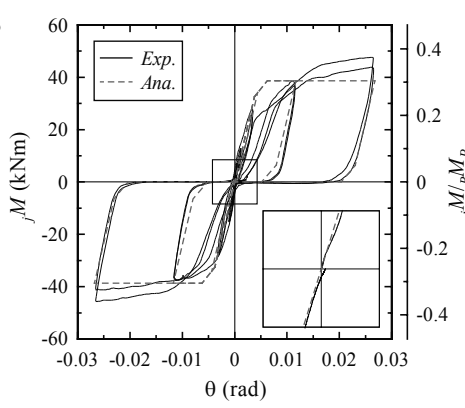

(a) $M-\theta$ 関係

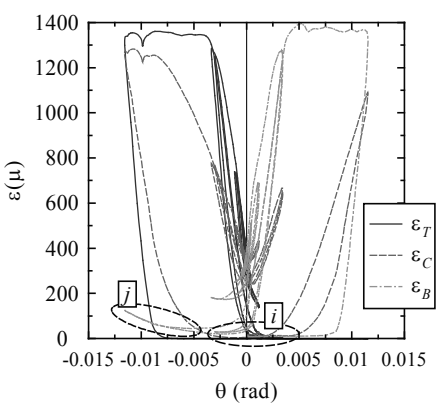

(b) $\quad \varepsilon-\theta$ 関係

\section{図 7 実験結果}

\section{4. 楔デバイスを用いたセルフセンタリング架構の数值解析}

本解析では，4層 4 スパンラーメン架構において，通常の梁降伏型 架構と楔デバイス付接合部を適用した架構の地震応答解析を行う。

\section{1 解析対象架構}

架構はパッシブ制振構造設計・施工マニュアル ${ }^{18)}$ の制振構造テー マストラクチャー4 層モデルを使用する. 対象架構は 4 層 4 スパンラー メン架構の Y2 構面とし, 梁中立軸を構造階高とするフレームモデル 一置換する．また，各荷重は事務所ビルを想定しており，各節点に 集中荷重として入力している. 設計条件として，1 次設計は，長期お よび短期の応力に対して断面検定を行っている．また， $A_{i}$ 分布に基 ら゙く荷重分布形を想定した静的荷重漸増解析を行い，層間変形角が 1/200rad 以下となるよう設計している．２次設計は，ある層の層間変 形角が $1 / 100 \mathrm{rad}$ に達した時点を保有水平耐力時とし, 必要保有水平 耐力を満足するよう設計している. 尚, 構造特性係数は $D_{s}=0.25$ とし ている.

\section{2 解析変数}

\section{2.1 解析モデル}

解析モデルは，通常架構と称する梁降伏型架構の $\mathrm{N}$ type と楔デバ イス付接合部を適用したセルフセンタリング架構である SC type の 
表 2 部材リストと断面性能

\begin{tabular}{|c|c|c|c|c|c|}
\hline 層 & 種別 & 断面寸法 & $\begin{array}{c}I_{x} \\
\left(\mathrm{~mm}^{4}\right)\end{array}$ & $\begin{array}{c}Z_{p} \\
\left(\mathrm{~mm}^{3}\right)\end{array}$ & $\begin{array}{c}M_{p} \\
(\mathrm{kNm})\end{array}$ \\
\hline 1 & \multirow{4}{*}{ 柱(C1) } & $\square-500 \times 500 \times 22$ & $1.61 \times 10^{9}$ & $7.55 \times 10^{6}$ & 2,452 \\
\hline 2 & & $\square-450 \times 450 \times 22$ & $1.15 \times 10^{9}$ & $6.05 \times 10^{6}$ & 1,966 \\
\hline 3 & & $\square-450 \times 450 \times 19$ & $1.02 \times 10^{9}$ & $5.30 \times 10^{6}$ & 1,722 \\
\hline 4 & & $\square-400 \times 400 \times 16$ & $6.05 \times 10^{8}$ & $3.54 \times 10^{6}$ & 1,151 \\
\hline \multirow{2}{*}{2} & 梁(G1) & H- $650 \times 250 \times 12 \times 25$ & $1.44 \times 10^{9}$ & $4.99 \times 10^{6}$ & 1,621 \\
\hline & ブラケット & BH- $650 \times 300 \times 16 \times 28$ & $1.91 \times 10^{9}$ & $6.64 \times 10^{6}$ & 2,157 \\
\hline \multirow{2}{*}{3} & 梁(G1) & H- $600 \times 250 \times 12 \times 22$ & $1.10 \times 10^{9}$ & $4.11 \times 10^{6}$ & 1,335 \\
\hline & ブラケット & BH- $600 \times 300 \times 16 \times 25$ & $1.46 \times 10^{9}$ & $5.52 \times 10^{6}$ & 1,795 \\
\hline \multirow{2}{*}{4} & 梁(G1) & H- $550 \times 250 \times 9 \times 19$ & $7.71 \times 10^{8}$ & $3.11 \times 10^{6}$ & 1,011 \\
\hline & ブラケット & BH $-550 \times 300 \times 12 \times 22$ & $1.05 \times 10^{9}$ & $4.25 \times 10^{6}$ & 1,382 \\
\hline \multirow{2}{*}{$\mathrm{R}$} & 梁(G1) & $\mathrm{H}-550 \times 200 \times 9 \times 16$ & $5.61 \times 10^{8}$ & $2.31 \times 10^{6}$ & 752 \\
\hline & ブラケット & BH $-550 \times 250 \times 12 \times 19$ & $8.04 \times 10^{8}$ & $3.31 \times 10^{6}$ & 1,075 \\
\hline
\end{tabular}



(a) $\mathrm{N}$ type

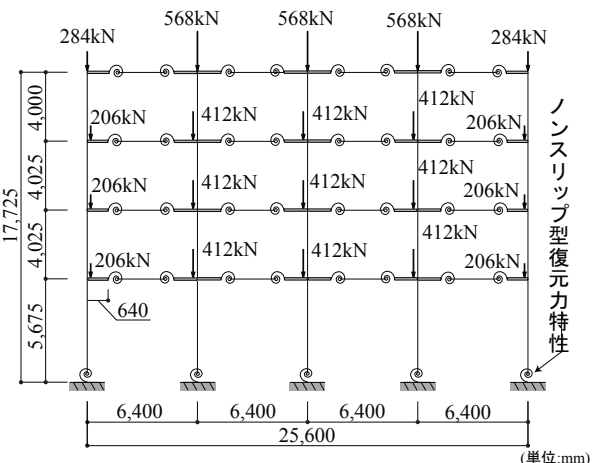

(b) SC type

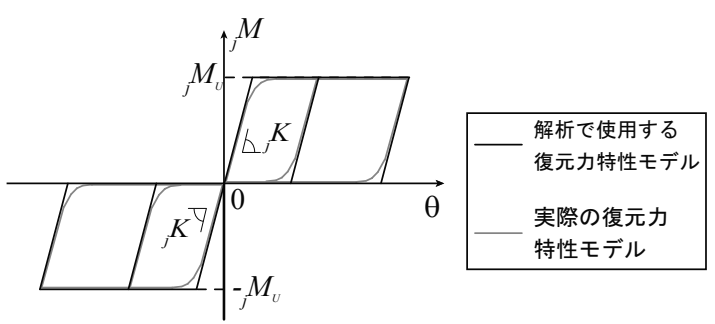

図 9 回転ばね特性値の定義

2 種類を用意する．接合部形式を変数とするが，SC type の梁継手に 楔デバイス付梁継手を, 柱脚にノンスリップ型露出柱脚を, それぞ れ想定した原点立上り型復元力特性を有する回転ばねを設ける。 N type は柱脚にのみ, アンカーボルト降伏型露出柱脚を想定したス リップ型復元力特性を有する回転ばねを設ける，回転ばね特性值は 表 3 に示寸通りであり，文字の定義を図 9 に示している。 また, SC typeには断面を増大させたブラケットを設け，ブラケット長さは ${ }_{B R} L=640 \mathrm{~mm}\left(\alpha_{j}=0.8\right)$ としている. 接合部最大曲げモーメント ${ }_{j} M_{U}$ を梁 の全塑性モーメント ${ }_{B} M_{P}$ で除した值としての接合部負担耐力係数 $\alpha_{j}$ を表 3 に示す.

本解析で用いる架構は，節点振り分け法で考えた際，4 層中柱柱 頭部に塑性ヒンジが生成される. SC typeにおいて, 柱頭に塑性ヒン ジを生成させず，楔デバイス付梁継手を機能させるため, 梁継手耐 力を低目の值で設計している. 従って, 4 層の保有水平耐力は $\mathrm{N}$ type と比較して小さくなる.

本解析の復元力特性モデルは，接合部のボルトの配置を多数配列 としているため, 引張抵抗するボルトの数だけ弾性勾配を生じる. しかしながら, 図 9 に示すように, 勾配の数が復元力特性の履歴面 積へ与える影響は少ないと判断できるため, Bi-linear 型の復元力特性
モデルとする．楔デバイス付梁継手に曲げモーメントが作用した場 合, エンドプレート端部を圧縮合力点位置とし, 最内列以外のボル トが引張抵抗する（露出柱脚は柱フェイス位置を圧縮合力点位置と する).また，Bi-linear型として表すため，引張抵抗を無視する最内 列ボルト以外が降伏した時点を最大耐力発揮時と考え, そのときの 接合部曲げモーメントを最大曲げモーメントとする. 尚, 楔デバイ ス付梁継手の回転ばねは第 3 章の載荷実験に基づき，ボルトのひず み硬化および初期張力の影響は考慮しない。また，ノンスリップ型 露出柱脚の回転ばねに関する実験結果は文献 12) を参照されたい.

数值解析では，接合部を回転ばねとし，以下の式を用いて各特性 值を算定する.

$$
M_{U}=\sum_{i=1}^{j-1} M_{Y i}
$$

${ }_{j} K=\sum_{i=1}^{j-1} K_{i}$

ここに, $j$ :ボルト列数である. 尚, 接合ボルトは ABR490を想定し, $\sigma_{Y}=325 \mathrm{~N} / \mathrm{mm}^{2}$ として $M_{U}$ を, $l_{b}=300 \mathrm{~mm}$ として ${ }_{j} K$ を, それぞれ算出し ている.

固有周期を表 4 に示寸. SC type の 1 次固有周期は N type より $0.05 \mathrm{~s}$ 長くなる.

\section{2.2 入力地震波}

地震波は平面骨組の構面内水平方向に入力する. 入力波には, El Centro 波 NS 成分, Taft 波 EW 成分, Hachinohe 波 NS 成分，および JMA Kobe 波 NS 成分の地動最大速度を，それぞれ $0.5 \mathrm{~m} / \mathrm{s}$ および $1.0 \mathrm{~m} /$ $\mathrm{s}$ となるよう, 地動最大加速度に係数を乗じて基準化した波を用いる. ただし，JMA Kobe 波は $1.0 \mathrm{~m} / \mathrm{s}$ 入力として原波を用いる. 


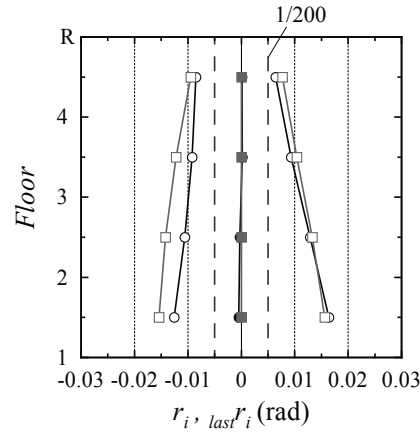

(a.1) El Centro

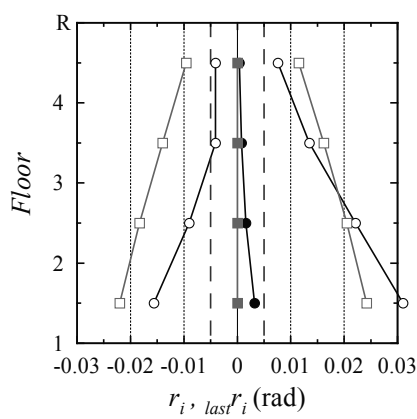

(b.1) El Centro

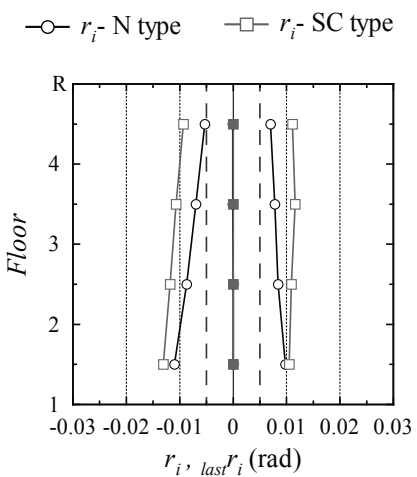

(a.2) Taft

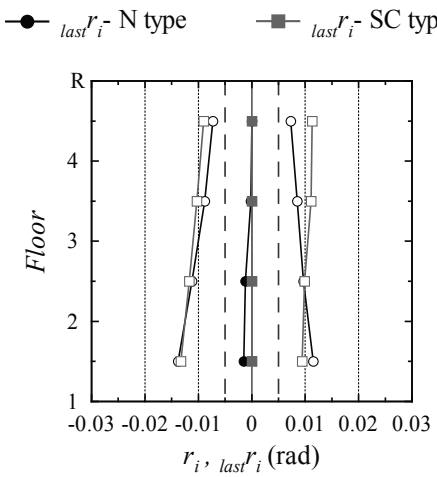

(a.3) Hachinohe

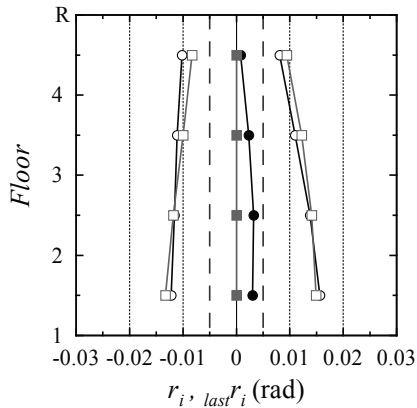

(a.4) JMA Kobe

(a) 最大速度 $0.5 \mathrm{~m} / \mathrm{s}$

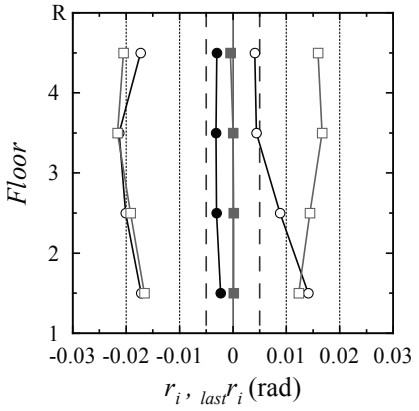

(b.2) Taft

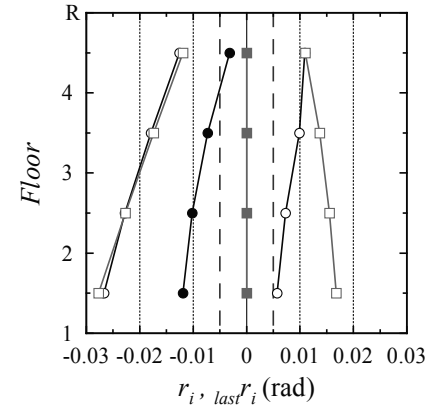

(b.3) Hachinohe

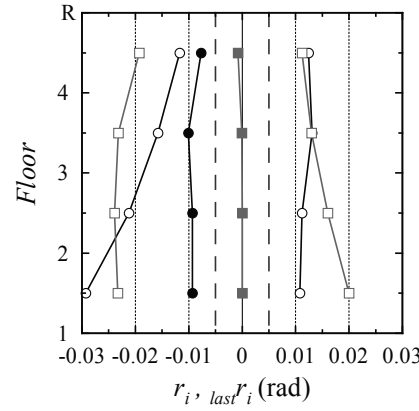

(b.4) JMA Kobe

(b) 最大速度 $1.0 \mathrm{~m} / \mathrm{s}$

図 10 層間変形角 · 残留層間変形角

\section{3 解析条件}

\section{3. 1 解析プログラム}

数值解析には，任意形平面骨組の複合非線形解析プログラムであ

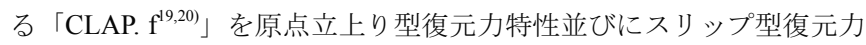
特性を有する回転ばねが利用できるようにコード修正したものを用 いる．使用プログラムは，節点移動や部材の変形に伴う幾何学的非 線形性が考慮される．部材の塑性化は，軸力と曲げモーメントの相 関関数で判定される一般化塑性ヒンジであり, 負荷挙動は移動硬化 則に従う。尚, 回転ばねは軸力の影響を考慮できない.また, 数值 積分にはニューマーク $\beta$ 法が用いられている.

\section{3. 2 解析条件}

本解析では, ニューマーク $\beta$ 法の $\beta$ 值 0.25 , 数值積分時間間隔 $1 / 200$ 秒，減衰のタイプは瞬間剛性比例減衰とし，一次減衰定数は一 般的な構造物を想定して 0.02 としている. 解析時間は, 地震入力の 終了後, 自由振動が十分に減衰するよう $70 \mathrm{~s}$ とする. また, 部材の応 力度 - ひずみ度関係は, Bi-linear 型（降伏後剛性比 1/100）としている. 尚, SC type は崩壊機構を形成した際, 梁端部に塑性ヒンジを形成す る $\mathrm{N}$ type とは異なり, 梁は鉛直方向に変位する。そのため, 鉛直荷 重と鉛直方向変位の積により仕事が生じるが，左右対称の崩壊機構 を形成すると仮定した場合, 鉛直荷重による仕事は左右で相殺しあっ て0となるので鉛直荷重の影響は無視している.

\section{4 解析結果}

本解析は 2 種類の解析モデルに，種類や大きさを変えた 8 種の地 震波を入力する，全16 ケースを行っている.

\section{4.1 最大層間変形角}

層間変形角·残留層間変形角を図 10 に示寸．図 10 の層間変形角は, ある一つの層が最大の層間変形角に達したときの変形形状を表して いる. $0.5 \mathrm{~m} / \mathrm{s}$ の結果を SC type に着目して N type と比較すると, El Centro・Taft で大きくなり, Hachinohe・JMA Kobe で変わらないか小 さ目の值を示している．地震波によって大小関係に差はあるが，楔 デバイス付梁継手を適用すれば， $0.5 \mathrm{~m} / \mathrm{s}$ の規模で両モデルが同様の 応答を示すことがわかる.

$1.0 \mathrm{~m} / \mathrm{s}$ の結果を見ると, $\mathrm{N}$ type と $\mathrm{SC}$ type $の$ 差が $0.5 \mathrm{~m} / \mathrm{s}$ より大きく, SC type が大きくなる傾向がある. SC type が大きくなるのは各層の 履歴性状の違いによるものである. 図 11 に Hachinohe $1.0 \mathrm{~m} / \mathrm{s} 1$ 層の 層間変形角時刻歴を示す. $\mathrm{N}$ type の場合, 塑性ヒンジの復元力特性 は完全弾塑性型であるため, 層せん断力が 0 となる変形角が負方向 にシフトする.一方で, SC type は原点立上り型復元力特性であるため, 塑性変形が生じても原点に戻る．図 11 のように N type は層間変形角 が一方向ヘシフトすることにより，一方向の最大応答が助長される 可能性があるが，SC typeでは解消されていることがわかる.

\section{4.2 残留層間変形角}

図 10 の残留層間変形角を見ると, $0.5 \mathrm{~m} / \mathrm{s}$ の地震波で生じる残留層 間変形角は, $\mathrm{N}$ type で最大 0.003 rad 程度 (JMA Kobe, 2 層), SC type では生じていない，楔デバイス付接合部の塑性ヒンジの復元力特性 が原点立上り型であるために残留変形角を生じないことがわかる.

$1.0 \mathrm{~m} / \mathrm{s}$ では, N type で 1/100rad を超える残留変形角を生じさせる 地震波であっても，SC type であれば残留変形角をほぼ生じていない (0.001 rad 以下)，楔デバイス付接合部の復元力特性によって, 地震動 


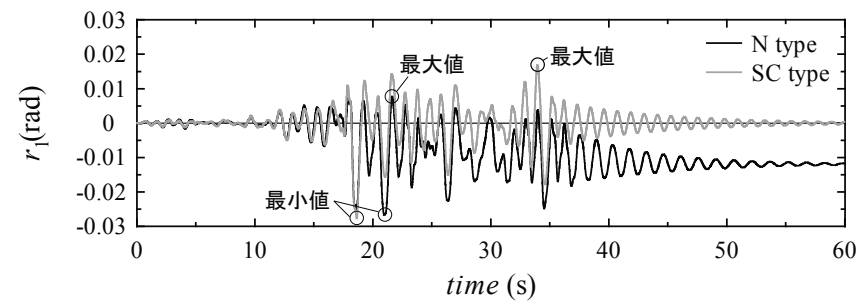

図 11 Hachinohe $1.0 \mathrm{~m} / \mathrm{s} 1$ 層の層間変形角時刻歴

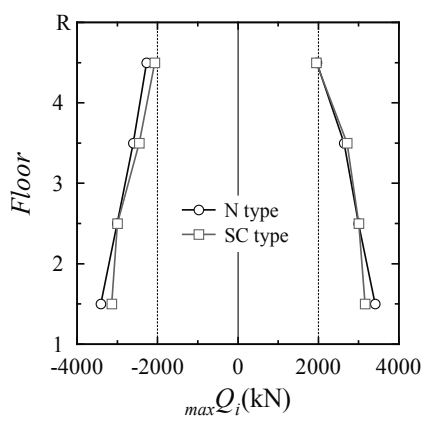

図 $12 \mathrm{EI}$ Centro $1.0 \mathrm{~m} / \mathrm{s}$ 最大層せん断力分布

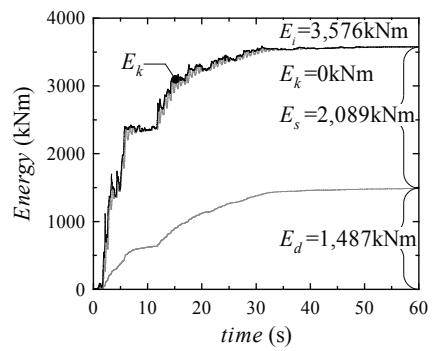

(a) $\mathrm{N}$ type

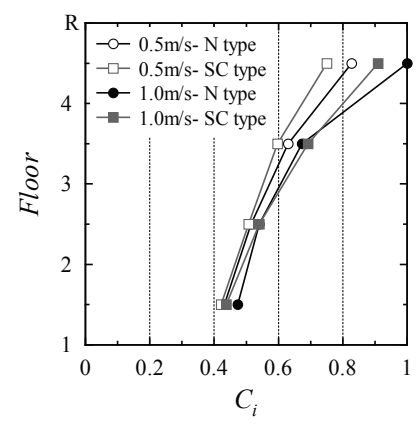

図 13 El Centro 層せん断力係数分布

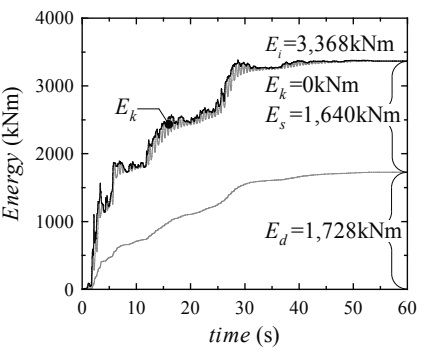

(b) SC type

図 $14 \mathrm{El}$ Centro 1.0m/s エネルギー応答時刻歴

の大きさに関係なく残留変形を低減できる.

$\mathrm{N}$ type において, 地震後の継続使用の可否について検討する. 地 震後の構造物の継続使用の可否を判断する指標として, 文献 21) で は許容残留変形角 $1 / 200 \mathrm{rad}$ が提案されている.これを見ると, $0.5 \mathrm{~m} /$ $\mathrm{s}$ 入力ではすべて 1/200 rad を下回り, $1.0 \mathrm{~m} / \mathrm{s}$ 入力では El Centro・Taft で下回るが, Hachinohe・JMA Kobe で上回る. Hachinohe やJMA Kobe のように大きな残留変形角を生じるのは, 図 11 のように, 一 方向に大きな塑性変形が生じる場合である. El Centro・Taft のように 残留変形角が小さいケースは塑性変形が正負両方向に生じ, 各方向 の塑性変形を相殺しあったためである。

\section{4.3 最大層せん断力分布 $\cdot$ 層せん断力係数分布}

最大層せん断力分布を図 12 に示す. 図 12 より，層せん断力は同 様であり, 図 2(b) に従い設計することで, 楔デバイス付梁継手を用 いても $\mathrm{N}$ type と比較して耐力が大きく低下しないことがわかる.

層せん断力係数分布を図 13 に示寸. 図 13 より, 層せん断力係数 $C_{i}$ は $0.5 \mathrm{~m} / \mathrm{s}, 1.0 \mathrm{~m} / \mathrm{s}$ ともに, 両モデルとも同様の形状を示す. $\mathrm{N}$ type と SC type を比較して, 分布が変わらないことから，楔デバイスを用 いたセルフセンタリング架構としても外力分布に変わりがなく, 通 常と同様の設計用外力により設計可能である.

\section{4.4 エネルギー吸収性能}

原点立上り型復元力特性は紡錘型の復元力特性に比べ, 第 $2 \cdot 4$ 象 限に履歴が生じず, 履歴吸収エネルギーが小さくなると予測される.

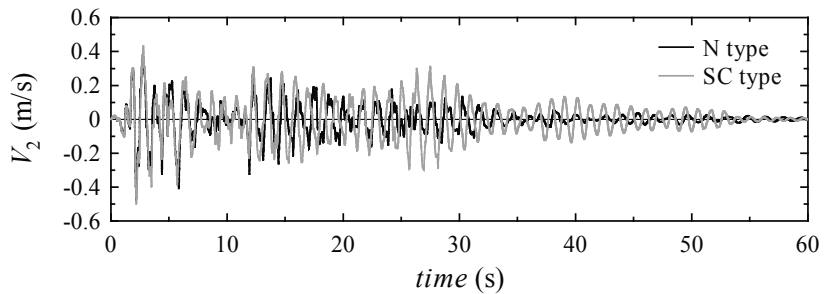

(a) 2 層

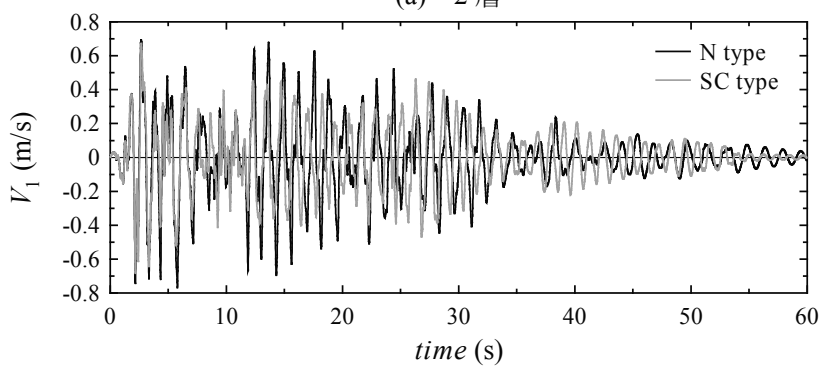

(b) 1 層

図 $15 \mathrm{EI}$ Centro $1.0 \mathrm{~m} / \mathrm{s}$ 速度応答時刻歴

ここでは，両解析モデルのエネルギー吸収性能について検討する.

El Centro $1.0 \mathrm{~m} / \mathrm{s}$ エネルギー応答時刻歴を図 14 に示寸. 図中 $E_{d}$ は 減衰エネルギー, $E_{s}$ はひずみエネルギー, $E_{k}$ は運動エネルギーであり, これらの総和は地震入力エネルギー $E_{i}$ に等しい. 尚, El Centro のみ の結果を示しているが，他の地震波でも同様の結果である.

図 14 より, $\mathrm{N}$ type と $\mathrm{SC}$ type の $E_{i}$ の差は 1 割以下でほぼ等しい. しかしながら， $E_{d}$ と $E_{s}$ の割合に違いがある. SC type は $E_{d}$ が大きく, $E_{s}$ が小さい. $E_{s}$ が小さいのは上述したように, 履歴性状の違いのた めである. $E_{d}$ は速度に影響を受け, 図 15 の速度応答時刻歴を見ると, 2 層で N type より SC type の方が速度が大きいことがわかる．速度が 大きくなるのは，接合部の回転角を 0 に戻す領域において，架構の 剛性が低下し, 単位時間当たりの変位増分が大きくなるためである. 尚， 1 層においては， N type の柱脚がスリップ型であるため SC type より $\mathrm{N}$ type が大きくなる. 2 4 層では図 15(a)のように SC type が 大きくなる. SC type は $E_{s}$ が小さい分, $E_{d}$ が大きくなり, $E_{i}$ が $\mathrm{N}$ type と変わりがない。

\section{4.5 損傷量}

架構の損傷量を最大塑性率 ${ }_{\text {max }} \mu$ と累積塑性変形倍率 $\eta$ によって判 断する. また，ボルト接合部の損傷は，ボルトの伸び性能に依存す るため, 最大累積塑性変形倍率 ${ }_{\text {max }} \eta$ で表す. これらの值の最大值が 最も大きかった El Centro $1.0 \mathrm{~m} / \mathrm{s}$ 損傷分布を図 16 に示す.

図 16 中の最大塑性率 ${ }_{\text {max }} \mu$, 累積塑性変形倍率 $\eta$, 最大累積塑性変 形倍率 ${ }_{\text {max }} \eta$ は下式で表す。

$$
\begin{gathered}
{ }_{\max } \mu=\max \left(\frac{\max _{p} \theta_{p}^{+}}{\theta_{Y}}, \frac{\max ^{-} \theta_{p}^{-}}{\theta_{Y}}\right) \\
\eta=\frac{\sum \theta_{p}^{+}+\sum \theta_{p}^{-}}{\theta_{Y}} \\
{ }_{\max } \eta=\max \left(\frac{\sum \theta_{p}^{+}}{\theta_{Y}}, \frac{\sum \theta_{p}^{-}}{\theta_{Y}}\right)
\end{gathered}
$$

ここに, ${ }_{\text {max }} \theta_{p}^{+}$: 正方向の最大塑性回転角, ${ }_{\text {max }} \theta_{p}^{-}$: 負方向の最大塑 性回転角, $\theta_{Y}$ : 降伏回転角, $\Sigma \theta_{p}^{+}$: 正方向の累積塑性回転角, $\Sigma \theta_{p}^{-}$: 負方向の累積塑性回転角である. 尚, $\mathrm{N}$ type と SC type は $\theta_{Y}$ が異な 


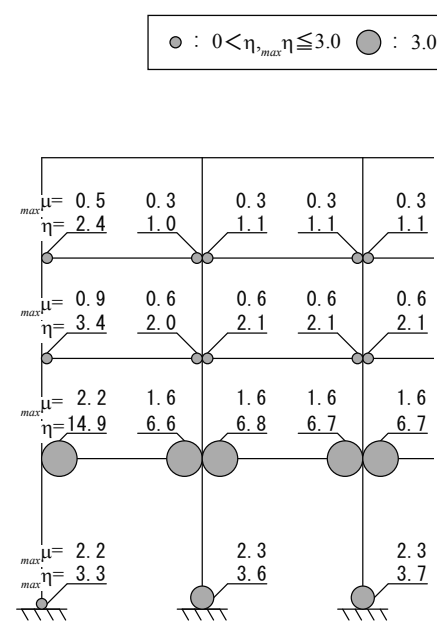

(a) $\mathrm{N}$ type

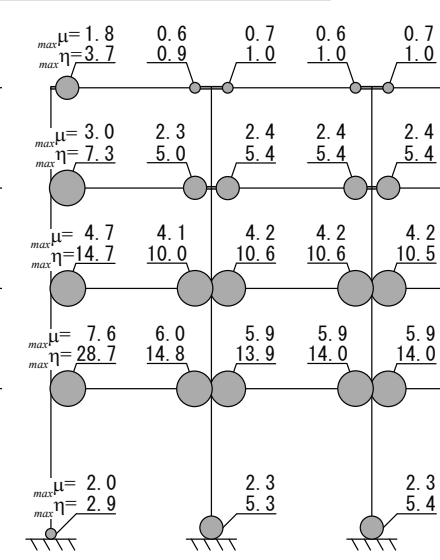

(b) SC type
図 $16 \mathrm{El}$ Centro $1.0 \mathrm{~m} / \mathrm{s}$ 損傷分布

るため数値の比較はできない. それぞれの解析モデルにおいて, 損 傷が設定する基準值を超えるかを判断する.

\section{4. $5.1 \mathrm{~N}$ type $の$ 損傷}

$\mathrm{N}$ type における損傷の判断基準として, 局部座屈が生じるか否か を指標とする．鋼構造限界状態設計指針・同解説 ${ }^{22)}$ では，変形性能 を確保するための構造区分が定められており, 最も変形性能が高い とされる場合に梁へ生成される塑性ヒンジの塑性率 $\mu$ が 4 程度と示 されている. 文献 3) では梁の繰返し載荷実験を行っているが, 局部 座屈を生じるときの累積塑性変形倍率 $\eta$ は, 小さいもので 10 前後で ある. これらから, 本解析で用いる局部座屈に対する判断指標として, 最大塑性率 ${ }_{\text {max }} \mu$ においては 4 , 累積塑性変形倍率 $\eta$ にあっては 10 を 用いる。

図 16 の $\mathrm{N}$ type を見ると, ${ }_{\text {max }} \mu=4$ を超えているケースはないが, 1 層側柱梁端部で $\eta=10$ を上回っている. $1.0 \mathrm{~m} / \mathrm{s}$ の大きさであれば，損 傷の大きい 1 層梁端部で局部座屈を生じる可能性がある.

\subsubsection{SC type の損傷}

SC type の損傷量の評価は, 接合ボルトがエネルギー吸収要素とな るため, ボルトの伸び量によって行う．楔デバイス付接合部に用いる ボルトは，10\%の伸び量が保証されている転造対じアンカーボルトを 用いているため，ボルトの塑性伸びが $10 \%$ 以下となるかを確認する.

最も累積塑性変形倍率が大きいのは 1 層側柱梁継手で ${ }_{\text {max }} \eta=28.7$ で ある。ボルトの弾性限界ひずみ度を ABR490を使用しているため $0.16 \%$ とすると, 累積塑性変形倍率を乗じれば $4.6 \%$ となる. 復元力 特性を Bi-linear 型と近似しているため, 最外列ボルトの塑性伸びは もう少し大きくなるが, $10 \%$ と比べれば十分余裕があり, 楔デバイ ス付梁継手の変形能力内にあることがわかる．また，余震等に対す る安全性も十分確保されている.

楔デバイス付梁継手はボルトをエネルギー吸収要素とする接合部 である，そのディテールから，損傷が大きくなったボルトの交換が 可能である，楔デバイスを用いたセルフセンタリング架構は，地震 時に仕上げ材等が損傷することがあっても, 接合ボルトに損傷を集 中させる機構であるため, 架構に残留変形は生じない, そのため, 地震後は損傷した仕上げ材等の補修や損傷したボルトの交換を行う ことで地震後も構造物を継続的に使用できる.

\section{5. 結論}

本論文は地震後継続使用を可能にする楔デバイスを用いたセルフ センタリング構造システムを提案し, 載荷実験及び数值解析よりそ の耐震性能を明らかにした。得られた知見を以下に示す.

1) 楔デバイス付梁継手は, 原点立上り型復元力特性を示し, セルフ センタリング性能を有している.

2) ボルト初期軸力の消失直後のサイクルで中央のボルト列の抵抗が 遅れることにより，剛性が若干低下寸るものの，それ以外の弾性 剛性・除荷剛性は復元力特性モデルと良好に対応する．よって本 復元力特性モデルにより評価できる.

3) 楔デバイスを用いたセルフセンタリング架構は， $0.5 \mathrm{~m} / \mathrm{s}$ の地震波 において, 最大層間変形角が通常の架構と同等である.

4) セルフセンタリング架構は, 通常の梁降伏型架構が継続使用が困 難なほど大きな残留変形角が生じる場合（層間変形角で $1 / 200 \mathrm{rad}$ ） においても，ほとんど残留変形角を生じない。

5) セルフセンタリング架構は, 復元力特性の影響によりひずみエネ ルギーが小さいが, 速度応答が大きくなるため減衰エネルギーが 大きくなる. 総エネルギーで見れば, 通常の架構と大差ない.

6) 応答層せん断力係数が通常架構と同様であることから, セルフセ ンタリング架構を設計する際に用いる地震荷重は一般的な場合と 同様に仮定すれば良い.

7) 通常架構の場合, 過大な地震力（最大速度 $1.0 \mathrm{~m} / \mathrm{s}$ ) が作用すると, 梁に局部座屈が生じ, 塑性ヒンジとしての変形性能を確保できない 場合がある.

8)一方，楔デバイス付梁継手を用いた架構は，塑性ヒンジとしての 変形性能が $1.0 \mathrm{~m} / \mathrm{s}$ の入力についても残存している．また，ボルト の有効長さを更に大きくできるディテールであるため, 設計用地 震動を大きくする場合，ボルトの有効長さを長くすれば，高い変 形性能を得ることができる．このように，楔デバイス付梁継手は， 非常に高い変形性能を有する塑性ヒンジとしての機能を有する.

今後の課題として以下のことが挙げられる.

楔デバイス付梁継手は，実構造物においてボルトが塑性化する程 度の回転角が生じた際，㨭れに対して十分な剛性を持って抵抗でき るか検証を行えていない，実験および FEM 解析等で詳細な検討を行 う必要がある.

また，梁の上部には床スラブが取り付き，エンドプレートの離間 が拘束されることが考えられる，著者等は，デッキ合成スラブを有 寸る楔デバイス付梁継手の載荷実験 ${ }^{23)}$ を行い, 離間が拘束されない ことを明らかにしたが，合成効果により剛性・耐力が増加するとい う新たな課題を得ている. 更に, 本論文における数值解析ではボル トのひずみ硬化による耐力の増加を適切に考慮しておらず, 仮定し た崩壞機構とは異なる崩壊機構を形成する可能性がある. 床スラブ やボルトのひずみ硬化の影響を適切に考慮した復元力特性モデルを 用い, 数值解析を行う必要がある.

更に, 楔デバイス付梁継手は, エンドプレート間で接触・離間が 発生する接合形式であり, エンドプレート回転時に, 梁の軸伸びが 生じ, 柱の拘束効果によって, 接合部に圧縮軸力 ${ }^{24)}$ が生じることが 考えられる. 軸力が作用することによって, 母材 (梁・ブラケット) の降伏曲げモーメントが低下するため, 降伏要素がボルト接合部か 
ら母材へ替わり，設計クライテリアが満足されない可能性がある. 軸力については，定量的な評価を行うことができれば，設計によっ て問題を解決することはできると考えているが，本論文では，これ らを考慮した検討は行えていない，柱の拘束効果による圧縮軸力の 定量的な評価方法を明らかにすることで, 復元力特性モデルの定式 化を行い，より実状に近い検証をする必要がある.

\section{謝辞}

本研究で使用した転造ねじアンカーボルトは “フルサト工業株式 会社”より提供していただきました。ここに記して感謝の意を表し ます。

\section{参考文献}

1）日本建築センター：2007 年版建築物の構造関保技術基準解説書, 2007.

2) 日本建築学会 : 兵庫県南部地震における鋼構造物の被害と教訓, 1996.7 .

3) 木村祥裕：局部座屈崩壊型 $\mathrm{H}$ 形鋼梁の塑性変形性能と累積塑性変形性能に 及ぼす載荷履歴特性の影響 - 片持ち梁形式の載荷実験データベースの構築 -, 日本建築学会構造系論文集, 第 76 巻, 第 664 号, pp.1143-1151，2011.6.

4) 木村祥裕, 山西央朗, 笠井和彦 : 交番繰返し軸力を受ける H 形鋼梁の繰返 乙履歷挙動と保有性能, 日本建築学会構造系論文集, 第 78 巻, 第 689 号, pp.1307-1316, 2013.7.

5) J. M. Ricles, R. Sause, S. W. Peng, L. W. Lu : Experimental evaluation of earthquake resistant posttensioned steel connections, ASCE Journal of Structural Engineering, pp.850-859, 2002.7.

6) 中島正愛, 吹田啓一郎, 池永昌容, 松宮智央, 倉田真宏 : セルフセンタリ ング導入による鋼構造骨組の残留変形低減効果, 日本建築学会大会学術講 演梗概集，C-1，構造 III，pp.765-766，2004.8.

7) 池永昌容, 長江拓也, 中島正愛, 吹田啓一郎 : ダンパー付きセルフセンタ リング柱脚の開発と大変形下の挙動, 日本建築学会大会学術講演梗概集, C-1，構造 III，pp.643-644，2005.9.

8) 池永昌容, 長江拓也, 中島正愛, 吹田啓一郎 : 残留変形低減をめざしたセ ルフセンタリング柱脚の開発と載荷実験, 日本建築学会構造系論文集, 第 612 号, pp.223-230, 2007.2

9) J. F. Hajjar, A. H. Sesen, E. Jampole, A. Wetherbee : A synopsis of sustainable structural systems with rocking, self-centering, and articulated energy-dissipating fuses, Northeastern University, 2013.6.
10) Takao TAKAMATSU, Hiroyuki TAMAI : Non-slip-type restoring force characteristics of exposed-type column base, Journal of Constructional Steel Reserch, Vol.61, pp.942-961, 2005.

11) 高松隆夫, 玉井宏章, 山西央朗 : ノンスリップ型鉄骨露出柱脚の復元力特 性モデル，構造工学論文集，Vol. 51 B，pp.293-302，2005.4.

12) 山西央朗, 高松隆夫, 玉井宏章, 松尾彰: アンカーボルトを多数配列した ノンスリップ型露出柱脚の復元力特性 - 無軸力下の場合のセルフセンタリ ング性能，日本建築学会構造系論文集，第 621 号, pp.155-162, 2007.11.

13) 澤田樹一郎, 高松隆夫, 玉井宏章, 松尾彰, 山西央朗 : 地震応答解析によ るノンスリップ型露出柱脚付鋼構造骨組のセルフセンタリング性能と累積 損傷応答評価, 日本建築学会構造系論文集, 第 73 巻, 第 629 号, pp.11511157, 2008.7.

14) 弘永佑太，高松隆夫，玉井宏章，山西央朗，田邊真二郎，澤田樹一郎，松 尾彰: 楔デバイス付接合部を有した構造物の残留変位に関する研究 その 1 載荷実験, 日本建築学会大会学術講演梗概集, C-1, 構造 III, pp.735736, 2010.8 .

15) 田邊真二郎, 高松隆夫, 玉井宏章, 山西央朗, 弘永佑太, 澤田樹一郎, 松 尾彰: 楔デバイス付接合部を有した構造物の残留変位に関する研究 その 2 数值解析, 日本建築学会大会学術講演梗概集, C-1, 構造 III, pp.737738, 2010.8.

16) 社団法人日本鋼構造協会 : 建築構造用アンカーボルトを用いた露出柱脚設 計施工指針・同解説, 2009.10.

17) 秋山宏 : 鉄骨柱脚の而震設計, 技報堂出版, 1985.3 .

18) 日本免震構造協会 : パッシブ制振構造設計施工マニュアル, 2003.10.

19) 小川厚治, 多田元英 : 柱・はり接合部変形を考慮した静的・動的応答解析 プログラムの開発，第 17 回情報・システム・利用技術シンポジウム論文集， pp79-84, 1994.12.

20) 多田元英 : CLAP.f 利用説明書 - 解析方法説明書, 鋼材俱楽部

21) 油野弘, 池永昌容, Jason McCormick, 中島正愛 : 居住性・施工性・安全性 指標に基づく建物の許容残留変形評価，日本建築学会構造系論文集，第 73 巻, 第 624 号, pp.325-331, 2008.2.

22) 日本建築学会 : 鋼構造限界状態設計指針・同解説, 2011.2.

23) 景山朋定, 高松隆夫, 玉井宏章, 山西央朗, 國井翔平：コンクリートスラ ブによる楔デバイス付梁継手の変形性状一の影響, 日本建築学会中国支部 研究報告集，CD-ROM 論文番号 -224, 2015.3.

24) 吉敷祥一, 山田哲 : 高力ボルト半剛接合部に対する柱の拘束効果に関する 基礎検討，鋼構造年次論文報告集，第 17 巻, pp.81-86, 2009.11. 


\section{STUDY ON SEISMIC PERFORMANCE OF \\ SELF-CENTERING STEEL FRAME WITH WEDGE DEVICE \\ Tomosada KAGEYAMA*, Takao TAKAMATSU**, Hiroyuki TAMAI ***,
Teruaki YAMANISHI ${ }^{* * * *}$, Shohei KUNII**** and Takanobu IWASE \\ * Grad. Stud., Grad. School of Sci. \& Tech., Hiroshima Institute of Technology \\ ** Prof., Dept. of Architectural Eng., Hiroshima Institute of Technology, Ph.D. \\ *** Prof., Dept. of Eng., Nagasaki University, Dr.Eng. \\ **** Assist. Prof., Grad. School of Eng., Hiroshima University, Dr.Eng. \\ ***** Oh-hata Architects \& Partners, M.Eng.}

Horizontal load-carrying capacity design is employed to estimate the seismic safety of steel frames subjected to a huge earthquake. This method has advantages that a frame designed with an all-story collapse mechanism formed by plastic hinges at beam ends and column bases as a maximum strength of the frame can be prevented from collapse. However, the plastic hinges at the beam ends have perfect elasto-plastic restoring force characteristics, so that the frame may retain residual deformation after the earthquake. Excessive residual deformation prevents continuous use of the damaged frame, and jammed doors or windows prevent refuge or rescue. Plastic hinges at beam ends cannot maintain plastic deformation performance due to local buckling.

This study aims to solve these problems by use of connections equipped with wedge devices. These connections show linear-from-origin-type restoring force characteristics and reduced residual deformation. A non-slip-type exposed column base was proposed as an earthquake-resisting element, but it was not assessed as a tool for reducing residual deformation of multi-story frames. A beam-to-column connection with a wedge device was proposed as an element for reducing residual deformation, but it showed larger response displacement than other devices.

A beam joint with a wedge device is proposed as an element for reducing residual deformation with similar response displacement. The beam joint with the wedge device is a joint connected by conventional bolts with the wedge device as a semi-rigid connection with no decrease in load-carrying strength of the frame. A frame with these bolted joints is expected to behave as a conventional frame in terms of load-carrying strength, stiffness, and response displacement. Furthermore, the joint connected by bolts with annealed screws having sufficient plastic elongation shows efficient plastic deformation performance. Loading tests on the beam joint with the wedge device were carried out to clarify the restoring force characteristics of the joint and numerical analyses on the frame with these joints were conducted to evaluate the seismic performance of multi-story frames.

Cyclic loading tests on a T-type assemblage specimen with the beam joint were conducted to examine the linear-from- origin-type restoring force characteristics. The experimental results show good agreement with a model of restoring force characteristics predicting cyclic behavior of the beam joint.

The numerical analyses on four-story frame models with/without the self-centering connections were conducted for comparison. Various types and magnitudes of earthquakes were selected for seismic response analyses of the frames. The analytical results verify that the self-centering connections reduce the residual deformations of the frames, having similar response displacement to a conventional frame. Story shear forces and story shear coefficients are also similar. The difference between the energy absorption capacities of the two types of frames is clarified by describing the energy absorption capacity of the frame and each plastic hinge. Beam joints with these wedge devices can play a significant role in resisting aftershocks. 